\title{
Earl Rögnvaldr of Orkney, a Poet of the Viking Diaspora
}

\author{
Judith Jesch*
}

\begin{abstract}
Kali Kolsson, later Rögnvaldr, Earl of Orkney, is a truly international figure who was born in Norway, travelled to England, came to power in Northern Scotland, and then made a memorable journey through Europe and the Mediterranean to the Holy Land. His poetry, composed in all of these places, survives only in Icelandic tradition and Icelandic manuscripts. This paper argues that the career and poetry of Rögnvaldr exemplifies the variation typical within a dispersed but interconnected culture, which might be termed the "Viking diaspora". Rögnvaldr was by training a Norwegian poet, but by practice and influence an Icelandic and Orcadian - indeed a European - poet. Each of these places had its own version of the culture, some of which shared a common derivation from the Scandinavian homeland, but much of which was rather the product of the dispersion from that homeland. By examining his poetry, and his interest in runic writing, it is possible to exemplify the diasporic process in which inherited cultural traditions from the homeland are reinvigorated and even reinvented in the context of multilateral cultural encounters.
\end{abstract}

\section{Introduction}

Kali Kolsson, later Rögnvaldr, Earl of Orkney, ca. 1103-1158, is a truly international figure (Crawford 2004, Jesch 2009a:575). He was born in Norway. He travelled to England with some traders in his youth. He then came to power in Northern Scotland. He made a memorable journey through Europe and the Mediterranean to the Holy Land. His poetry, composed in all of these places, survives only in Icelandic tradition and Icelandic manuscripts. So how should he be characterized? Where can he be placed in the Scandinavian, North Atlantic, or European cultural landscapes? Is he a Norwegian poet by virtue of his birth, an Orcadian poet by virtue of his place of residence in adulthood, or an Icelandic poet by virtue of the fact that his poetry survives only in Icelandic texts?

$\mathrm{He}$ is, of course, all of these things. But to use these categories is to impose modern political boundaries on a medieval phenomenon that was linguistic and cultural. People in the Viking period and the following centuries spoke the same language from Birka to Brattahlíð, and were in regular contact with each other, in matters cultural, political, and mercantile. Yet each of the places in this globalized world also had its own version of the culture, some of which shared a common derivation from the Scandinavian homeland, but much of which was rather the product of the dispersion from that homeland. The career and poetry of Rögnvaldr is an illustration of this variation within a dispersed but interconnected culture, which might be termed the "Viking diaspora" (Jesch 2008).

\section{The Norwegian Background}

According to Orkneyinga saga (ch. 42), Rögnvaldr was born as Kali Kolsson, son of the king's nobleman Kolr Kalason and his wife Gunnhildr Erlendsdóttir. ${ }^{1}$ She was Orcadian, the sister of the martyred St. Magnús. The couple also had a daughter, Ingiríðr, and it is said that the two young people were both very promising and were brought up in a loving family. They all lived in the south of Norway, somewhere in Agder. Kali was named after his paternal grandfather, Kali Sæbjarnarson, also from Agder, and we are told (ch. 39) that this first Kali was a wise man, beloved of King Magnús barelegs, and a good poet.

Kali junior was brought up in the home of his father Kolr, whom the saga describes as the wisest of men (ch. 58). It is emphasized that Kolr did not sail to Orkney, and we must assume that his son did not either, at least in his youth, when it would in any case have been politically inadvisable in those years just after the martyrdom of St Magnús. Kali is described as promising, well-built and of middle height, with well-shaped limbs and chestnut hair. He is both popular and more enterprising than most. It is also said that he often visited his kinsman Sölmundr, a town official in Tønsberg who had a farm in AustAgder. Sölmundr is said to have been the same age as Rögnvaldr, but he was already a chieftain with a large following.

Kali went to Bergen at the age of fifteen, after his first trip to England with some traders (ch. 60). The saga gives a colorful picture of Bergen at that time, with people coming from all over Norway and foreign countries too. This environment clearly suited Kali, who is said to have dressed in a showy fashion with

\footnotetext{
"Centre for the Study of the Viking Age, School of English, University of Nottingham, Nottingham, NG7 2RD, UK; Judith. Jesch@nottingham.ac.uk.
} 
his English gear. Like other young men, Kali liked to go to the pub, and there he became friends with a young man from Sogn, Jón Pétrsson. A few years later, back in Bergen, the two friends fell out when their men argued over who were the most outstanding noblemen in Norway (ch. 61). The choice was between Jón on the one hand, and Kali's kinsman Sölmundr on the other, and it ended badly when Kali's man killed Jón's man. The feud is described in typical saga style, with wise advice from Kolr and several more killings, but ending with a settlement brought about by King Sigurðr jórsalafari. He suggested the killings could cancel each other out, and that Jón should marry Kali's sister Ingiríðr. He gave Kali half the earldom of Orkney, presumably to get him out of the way. He also gave him a new name, one that already had resonance in the islands, that of Rögnvaldr, after Earl Rögnvaldr Brúsason. The settlement was not broken, and the friendship was maintained: Jón appears quite a few more times in the saga in Rögnvaldr's following (chs $64,67,73,85-88)$.

Many years later Rögnvaldr went to Bergen again, invited by King Ingi Haraldsson (ch. 85). We get the impression that he had not been to Norway in the meantime, because the saga says he was very eager to visit his friends and relations there. He took the young Orcadian Earl Haraldr Maddaðarson with him and they travelled to Norway with some merchants. In Bergen, there was much talk of travels to Byzantium and Jerusalem, and Rögnvaldr agreed to lead such a voyage to the east. Many noblemen from Norway wanted to go with them. Some years later, the voyage took place, with Norwegians, Orkneymen, and Icelanders on fifteen big ships.

\section{Rögnvaldr's “Norwegian” Poetry}

What the saga tells us of Rögnvaldr's Norwegian background and connections suggests the question of what, if any, Norwegian background there was to his poetry. We do not know where Rögnvaldr's poetical talents came from. He may have learned his craft on his grandfather's knee in Agder. Or poetry may have been in the air in Orkney when he moved there. Or he may have learned it from the Icelandic friends he met in Bergen or who came to Orkney. There is, however, no evidence that Rögnvaldr ever visited Iceland himself.

There is also the thorny question of whether the surviving poetry which is attributed to Rögnvaldr really was composed by him in the $12^{\text {th }}$ century. A century ago, Hugo Gering (1911-1914) expressed doubt that Rögnvaldr really was the author of the stanzas relating to the voyage to Jerusalem, suggesting instead that both the episode itself and the stanzas were composed by the author of the saga. This hypothesis was comprehensively challenged by Rudolf Meissner (1925), and since then most scholars (Bibire 1988, Jesch 2009a) have accepted the stanzas for what they purport to be. Subsequent discussion has rather turned on their literary-historical significance as evidence for or against the influence of the troubadours on Old Norse poetry (Finlay 1995). Here I shall simply postulate that all the stanzas attributed to Rögnvaldr in Orkneyinga saga (and one or two other sources) are "genuine", i.e., that they were in fact composed by him in more or less the circumstances described by the saga, or something similar, a not unreasonable position given the range of evidence for a Norse literary culture in Orkney (Jesch 2009b).

Rögnvaldr's poetry reveals that he had both positive and nostalgic feelings for the land of his birth. A youthful stanza from his first trip to England expresses a strong contrast between the unpleasantly muddy trading town of Grimsby and the relief he felt when he was finally on his way home to Bergen (ch. 59; Jesch 2009a:577-578). ${ }^{2}$ This description of Grimsby is entirely correct. In the Middle Ages, the town was surrounded by mudflats and saltmarshes, and there was only one road into it. The Norwegian traders anchored out in the harbor and had to traipse through the mud every day to trade in the town.

Much later in life, when Rögnvaldr was attacking a fortification in Galicia at Christmastime, he remembered the Christmas feasts he and Sölmundr had had together "beside Agder's mountains" (ch. 87; Jesch 2009a:596-597). The stanza makes clear that the two young men held Christmas parties together, as joint hosts providing the feast. This sets up a nice contrast with the following stanza, in which Rögnvaldr boasts of how he is now feeding the eagle in Galicia (ch. 87; Jesch 2009a:597-598). It was the duty of a chieftain to provide food and drink for his followers, just as it was the duty of a warrior to provide food and drink for the beasts of battle.

The only one of Rögnvaldr's stanzas which is actually localized to Norway is another youthful one (ch. 61; Jesch 2009a:578-579). On a trading voyage to Trondheim, Kali, as he then still was, was held up by the weather on Sandøy in Sunnmøre. The crew went into a large cave on the island, now called Dollsteinshola, in the hope of finding treasure. When they came to a large lake in the cave, Kali and a servant of his were the only ones who dared cross it, which they did holding a rope between them. In addition, Kali had a torch in his hand and a strike-alight on his back. This adventure is immortalized in the stanza-although they did not find treasure, they did something no one else dared to do. 


\section{Rögnvaldr's Skills}

These are the stanzas which particularly relate to Rögnvaldr's Norwegian background. But some of his other stanzas provide further information about the origins of his poetry, in particular his wellknown stanza in which he boasts of nine skills (ch. 58; Jesch 2009a:576-577; see also Jesch 2006):

Tafl em ek örr at efla;

ípóttir kannk níu;

týnik trauðla rúnum;

tíðs mér bók ok smíðir.

Skríða kannk á skíðum;

skýtk ok rœk, svát nýtir;

hvártveggja kannk hyggja:

harpslátt ok bragpáttu.

(I am quick at playing board games; I have nine skills; I forget runes slowly; the book is a preoccupation with me and also craftsmanship. I am able to glide on skis; I shoot and I row so that it makes a difference; I am able to understand both: harp-playing and poems.)

Of the physical skills, shooting and rowing must have been common to all young men in the North at the time, but skiing was a typically Norwegian skill. In the whole of the large corpus of medieval Icelandic literature, skiing is rarely mentioned and when it is, it is always associated with Norway and Norwegians (Jesch 2005:130-131). So when Rögnvaldr says that he is "able to glide on skis", then it is his way of saying that he is Norwegian.

The other skills are of cultural interest. The first word in the stanza, tafl, clearly refers to some kind of board game, though which is not clear. The question is whether this is hnefatafl, a form of Fox and Geese, which is mentioned in Eddic poetry, or rather the more modern game of chess (Haugen 1982). The latter is very likely, in that chess was the latest fashion for young aristocrats in northern Europe in the $12^{\text {th }}$ century. There is clear evidence for this in the playing-pieces, made of walrus ivory, which are known from their find spot on the isle of Lewis in the Hebrides. It is now generally accepted that they were made in Trondheim, and date to the $12^{\text {th }}$ century. While it was previously thought that they had ended up in Lewis as the result of a shipwreck, and were perhaps on their way to market in Dublin, a recent detailed article by Caldwell et al. (2009) proposes that they were in fact the possessions of a chieftain on Lewis, and that some of the pieces could be used for games other than chess. If they really did belong to a Norse chieftain in the Hebrides, then this provides an even better parallel for Rögnvaldr's aristrocratic interest in the game, an interest that we can also tease out of another one of his stanzas.
Stanza no. 23 occurs in a somewhat obscure context concerning the Earl's companion Eindriði ungi who had previously allowed a Spanish leader called Guðifreyr to escape from the castle they were besieging during their "crusade" (ch. 87; Jesch 2009a:600-602). The Earl's fleet having sailed through the Straits of Gibraltar, Eindriði separates from it with six ships and heads towards Marseilles. Remarking that this reveals Eindriði's guilt in allowing Guðifreyr to escape from the besieged castle, Rögnvaldr and his men sail a southerly route along the coast of Africa. The stanza appears to be saying that Eindriði is a hrókr, which seems to mean a "scoundrel", but there may also be a chess subtext here. Hrókr is also the word for the chess piece known in English as the "rook". The word itself is originally Persian, and is found in both Latin and Anglo-Norman texts in England from the mid-12 $2^{\text {th }}$ century. In Old Icelandic, it is otherwise first found in the $14^{\text {th }}$ century in a chivalric saga where it seems to be derived from the French source. It is just the sort of word Rögnvaldr could have picked up before it reached Iceland. If the stanza does contain an underlying chess metaphor, then what it shows is Rögnvaldr's treacherous follower, Eindriði, moving in a straight line, like the rook, and attacked by the knight, i.e., Rögnvaldr himself, the only chess-piece that can move in a roundabout or "hooked" way.

There has also been discussion of what Rögnvaldr meant by his claim to understand "harp-playing". The first question is whether he actually played the harp, or whether he just claims to appreciate such music, as would be suggested by the most careful translation of the verb hyggja. Another question is what kind of instrument is meant by a "harp", and there are many possibilities, as discussed by the Swedish musicologist Ingrid de Geer (1985:220 227). An important contribution was made here by Barbara Crawford (1995). With the support of the musicologist Graeme Lawson and the art historian Martin Blindheim, Crawford argued that a statue that was until lately on Bishop Reid's Tower in Kirkwall dates to around 1300 , and that it portrays Rögnvaldr with a musical instrument that has several parallels in Norwegian art.

Rögnvaldr also boasts of his knowledge of runes, or rather, with typical Old Norse modesty, "I forget runes slowly". It must be obvious that this is a skill that Rögnvaldr picked up in Norway, given the large number of medieval inscriptions known from that country, but the question is worth more detailed consideration.

\section{Rögnvaldr and Runes}

Medieval runic inscriptions are known from all three of the towns with which Rögnvaldr is 
associated in Orkneyinga saga, Tønsberg, Bergen, and Trondheim. The most recent version of the Scandinavian runic database records 647 medieval inscriptions from Bergen, 160 from Trondheim, and 32 from Tønsberg (Samnordisk runtextdatabas 2008). Most of these are admittedly either undated or dated to later than Rögnvaldr's lifetime. The dating question is, however, still open, since most of these inscriptions have not yet received full scholarly publication, and many which are not dated could be from the relevant period. On the basis of current knowledge, there are only around 63 from Bergen which are dated to sometime in the $12^{\text {th }}$ century. But that is still not an insignificant number, and it is clear that there was much reading and writing of runes there in the $12^{\text {th }}$ century. It is thus highly likely that Rögnvaldr learned his runes in Bergen, using a stick with the runic alphabet on it, of which there are around 50 from Bergen, to practice his letters (Knirk 1994). There are also some 11 such inscriptions from Trondheim and 3 or 4 from Tønsberg.

Scandinavian runic writing is also found in the British Isles, including Shetland and Orkney. When Rögnvaldr moved to northern Scotland, he came to a society that must also have been familiar with this mode of communication. Yet there are relatively few runic inscriptions from northern Scotland that can securely be dated to before Rögnvaldr's time, and some of these are on loose objects that could have come from elsewhere. The remarkable flourishing of runic writing in Orkney actually occurs in Rögnvaldr's own time and it is likely that he and his associates were responsible, based on their experiences in Norway. Especially relevant in this context are the graffiti on the inside walls of the prehistoric chambered tomb of Maeshowe. Michael Barnes came to the conclusion that they were undoubtedly carved in the middle of the $12^{\text {th }}$ century and that they, or at least some of them, were carved by the voyagers to Jerusalem (Barnes 1994:38-43). Barnes is more cautious on the question of rune forms and the linguistic characteristics of the inscriptions, which could reveal the origins of the people who carved them. He assumes that some of the carvers were Norwegian, since Norwegians participated in the Jerusalem voyage, and because Norwegians already had the runic habit by then. He notes the paucity of inscriptions from Orkney in this period, and the even scantier Icelandic corpus, and concludes that it is less likely that the very accomplished Maeshowe carvers came from these countries, summing up as follows (Barnes 1994:41):

... the linguistic evidence must be regarded as inconclusive. There is no reason why nonNorwegian runic carvers should not have been active in the mound, but the lack of any material evidence outside Maeshowe of a thriving twelfth-century runic culture in the islands of the North Atlantic makes one think that the inspiration at least must have been Norwegian.

It is unfortunately impossible to point to any one inscription that must have been carved by Rögnvaldr himself. Nevertheless, there are some aspects of the carvings that point to him or his circle, and there is some overlap of interests between his poetry and these often witty carvings.

Several of the inscriptions mention the possibility of treasure in the mound: in fact, 6 out of the total of 33 inscriptions, or 6 out of those 16 inscriptions which have more than a carver's formula. These often jocular inscriptions can be compared with the Dollsteinshola episode mentioned above, which was also ostensibly about treasure. Two of the inscriptions link the idea of treasure directly to the Jerusalem-farers (Barnes 1994:114-118, 186-190). It is hard to escape the conclusion that the Maeshowe texts are just as much about Rögnvaldr's adventures as his own poetry is. He is in fact named, though only indirectly, in one of the Jerusalem-farer inscriptions, which claims to have been carved by his housekeeper.

Another link between Rögnvaldr's poetry and the Maeshowe inscriptions is their shared interest in women. While it is not surprising that men are interested in women, it is possible to read many runic inscriptions and skaldic poems from before Rögnvaldr's time without coming across a single reference to a real woman, so in this context the similarity is significant. Rögnvaldr is best known for his stanzas about Ermingerðr, Viscountess of Narbonne, in Provence, whom he met on his way to the Holy Land and who is named or referred to in 8 out of his 35 stanzas (Jesch 2009a:592-596, 597-600, 603). But other kinds of women are also mentioned in at least 5 of his other stanzas, not including a stanza in which he unflatteringly compares some monks to women. Of all these stanzas, only one (not preserved in the saga) appears to refer to his wife, a woman about whom we know precisely nothing, except that, since Rögnvaldr had a daughter (named Ingiríor after her aunt), a wife must be assumed to have existed (Orkneyinga saga, ch. 94; Bibire 1988:239).

One of Rögnvaldr's most interesting, if lesserknown, stanzas is no. 6 , also involving an encounter with a woman (ch. 81; Jesch 2009a:581-582):

Aldr hefk frétt, pats feldu

fránstalls konur allar

- verðrat menja myrðir

mjúkorðr - höfuðdúkum.

Nú tér Hlökk of hnakka 
haukstrindar sér binda

— skrýðisk brúðr við bræði

bengagls - merar tagli.

(I have always understood that all women wrapped themselves in headdresses of snake-support [GOLD]; the murderer of neckornaments [GENEROUS MAN $=$ Rögnvaldr] will not be gentle in his speech. Now the Hlökk $<$ valkyrie $>$ of the hawk-land [ARM $>$ wOMAN = Ragna] ties a mare's tale around her neck; the lady got dressed up for the feeder of the wound-gosling [RAVEN/EAGLE $>$ WARRIOR $=$ Rögnvaldr].)

According to the saga context, a certain Icelander called Hallr Pórarinsson arrived in Orkney and lodged on North Ronaldsay with a man called Porsteinn and his mother Ragna. Porsteinn took the Icelander to the Earl's court to get him accepted there, but without success, so Ragna had to take over. She went to see Rögnvaldr dressed in a red headdress made of horsehair. The stanza has its difficulties, and it is not entirely clear what it really means, except that it is undoubtedly an example of nið, that form of sexual insult so dear to the Vikings (Almqvist 1965-1974). One possible interpretation is that, in it, Rögnvaldr draws a contrast between the usual golden headdress of a fine lady, and Ragna's curious horsehair concoction. When he calls this a "mare's tail", he is alluding to the common association between mares and female sexuality. What is not quite clear in Rögnvaldr's stanza is whether he is accusing Ragna of nymphomania (the usual accusation when the ní insult is directed at a woman), or whether he thinks she is impugning his masculinity by appearing before him with an object associated with a female animal, which would be a form of nið addressed to a man. It seems that the saga author assumed the latter, since he says that Ragna claims in response that the headdress was from a stallion. In other words, Ragna is using the situation to claim she is more of a man than the Earl, and indeed she gets her way, and the Icelander Hallr is accepted at the Earl's court.

This stanza can be compared with inscription no. 9 in Maeshowe, which reveals some of the same attitudes (Barnes 1994:95-102):

$\S$ A Ingibjörg, hin fagra ekkja.

$\S \mathrm{B}$ Mörg kona hefir farit lút inn hér. Mikill ofláti.

$\S \mathrm{C}$ Erlingr.

(§A Ingibjörg, the fair widow.

$\S \mathrm{B}$ Many a wife has travelled stooping in here. A great show-off.

$\S \mathrm{C}$ Erlingr.)
This may merely refer to the undoubtedly low entrance to Maeshowe, which is only about $1 \mathrm{~m} \mathrm{high,}$ requiring all those who would enter to bend down. But which women would go to Maeshowe in the first place? Both Michael Barnes and Terje Spurkland $(2005: 147)$ are inclined to interpret the inscription in a more explicit way, with the implication of mörg being "loose" and/or that lutr "bent over" refers to the sexual act, an interpretation which receives some support from the content of inscription 10, which states baldly that "Porný fucked" (Barnes 1994:102105). Thus, inscription 9 can mean that the proud woman will have to submit sexually to the man, in this case probably Erlingr. This is more or less what Rögnvaldr says to Ragna in his stanza, implying that she has come to submit herself to him, she too having dressed up to show off. Both the inscription and the stanza are ambiguous in relation to how real the threat of sexual submission is, given that their contexts also allow for a more straightforward interpretation. And we may note that, although Ragna is not explicitly said to be a widow in Orkneyinga saga, there is no mention of a husband, and so her status, as well as her showiness, are parallel to that of the otherwise unidentified Ingibjörg in the Maeshowe inscription.

\section{Conclusion}

As a young man, Rögnvaldr grew up in a lively and flourishing Norway in the $12^{\text {th }}$ century, where people practiced traditional skills like skaldic poetry and runic writing, while also taking up new fashions such as chess and music. He hung out in the bustling trading centers of both Norway and abroad (Bergen, Trondheim, Grimsby), but also with politically important people in Tønsberg. This clever and well-travelled young man was thrust into a new role as Earl of Orkney, a place he most likely had not visited previously, but about which he must have heard from his mother. The saga shows in exhausting detail how difficult it was for him to take and keep power in Orkney, but this is not a topic that receives much attention in his poetry. Moreover, although he associated with several poets, he does not follow the old custom of having court poets to immortalize his deeds, there is no Rögnvaldsdrápa to sum up his career for us.

Instead, we have his own poetry on a host of other subjects, much of it highly innovative. The stanzas are often amusing and witty, and some are sarcastic. Quite a few of them are observations of ordinary people, serving-girls and madmen in Shetland, and monks in Orkney. Others are unflattering portraits of important people, such as Erlingr skakki, the future regent and father of the king of Norway, 
shown falling into the mud when drunk. Rögnvaldr's poetry is formally and linguistically innovative, as many of the words and phrases he uses are typical of the $12^{\text {th }}$ century but were unknown or rare before then. Whether or not he is the innovator, he is right in there with the latest poetical trends, just as he seems to be up with new fashions in runic writing and the playing of chess. According to the saga (ch. 81), he and the Icelander Hallr Pórarinsson, already mentioned, composed the poem Háttalykill, a key to meters with many metrical innovations, which was an important model for the poetological work of Snorri Sturluson.

The runic evidence from Bergen shows that skaldic poetry flourished in Norway throughout the Middle Ages, and was not a purely Icelandic phenomenon. It is very likely that Rögnvaldr learned this skill in Norway, too, perhaps on his grandfather's knee, or perhaps in Bergen at the same time as he picked up runes. It is significant that the contemporaneous practice of both skaldic poetry and extensive runic writing is best attested in only two places, medieval Bergen and $12^{\text {th }}$-century Orkney. It is not necessary to believe that Rögnvaldr's youthful poems were composed in his youth-his "nine skills" poem could just as well be retrospective as youthful boasting. The cave stanza discussed above could have been composed as the punch line to an amusing story about this episode, told many years later. But having learned the skill of poetry in his youth, Rögnvaldr's best, and certainly best preserved, poetry came later in his life, when he had experienced, and continued to experience, new countries, new cultures, and new people. He soaked up ideas from everywhere, breathing new life into skaldic poetry. He was, therefore, by training a Norwegian poet, but by practice and influence an Icelandic and Orcadian - indeed a European - poet. His poetry and his interest in runic writing exemplify the diasporic process in which inherited cultural traditions from the homeland are reinvigorated and even reinvented in the context of multilateral cultural encounters. Rögnvaldr demonstrates both internal diasporic connections, between Norway, the British Isles, and Iceland, and the external cultural connections deriving from his extensive travels in the south. The fact that his poetry was preserved in Icelandic texts demonstrates the Icelanders' consciousness of their ongoing connectedness to the various regions of the Scandinavian homelands and the Viking diaspora. ${ }^{3}$

\section{Literature Cited}

Almqvist, Bo. 1965-1974. Norrön niddiktning: Traditionshistoriska studier i versmagi, 1-2. Almqvist and Wiksell, Stockholm, Sweden. 260 pp. + 201 pp.
Barnes, M.P. 1994. The runic inscriptions of Maeshowe, Orkney. Institutionen för nordiska språk, Uppsala universitet, Uppsala, Sweden. 297 pp.

Bibire, P. 1988. The poetry of Earl Rognvald's court. Pp. 208-240, In B.E. Crawford (Ed.). St Magnus Cathedral and Orkney's Twelfth-Century Renaissance. Aberdeen University Press, Aberdeen, UK. 283 pp.

Caldwell, D.H., M.A. Hall, and C.M. Wilkinson. 2009. The Lewis hoard of gaming pieces: A re-examination of their context, meanings, discovery, and manufacture. Medieval Archaeology 53:155-203.

Crawford, B.E. 1995. An unrecognised statue of Earl Rognvald? Pp. 29-46, In B.E. Crawford (Ed.). Northern Isles Connections: Essays from Orkney and Shetland Presented to Per Sveaas Andersen. Orkney Press, Kirkwall, UK. 133 pp.

Crawford, B.E. 2004. Harald Maddadson, Earl of Caithness and Earl of Orkney (1133/4-1206), In Oxford Dictionary of National Biography. Oxford University Press, Oxford, UK. Available online at www. oxforddnb.com/view/article/49351. Accessed 11 November 2011.

De Geer, I. 1985. Earl, Saint, Bishop, Skald-and Music. The Orkney Earldom of the Twelfth Century: A Musicological Study. Uppsala Universitet, Uppsala, Sweden. 333 pp.

Finlay, A. 1995. Skalds, troubadours, and sagas. SagaBook 24:105-153.

Gering, H. 1911-1914. Die Episode von Rögnvaldr und Ermingerðr in der Orkneyinga saga. Zeitschrift für deutsche Philologie 43:428-434, 46:1-17.

Guðmundsson, F. 1965. Orkneyinga saga. Íslenzk fornrit 34. Hið íslenzka fornritafélag, Reykjavík, Iceland. $371 \mathrm{pp}$.

Haugen, O.E. 1982. Brettspel i nordisk mellomalder. Eigenproduksjon 13-14:1-37.

Jesch, J. 2005. Geography and travel. Pp. 119-135, In R. McTurk (Ed.). A Companion to Old NorseIcelandic Literature and Culture. Blackwell, Oxford, UK. 567 pp.

Jesch, J. 2006. The Nine Skills of Earl Rögnvaldr of Orkney. University of Nottingham, Nottingham, UK. $16 \mathrm{pp}$.

Jesch, J. 2008. Myth and cultural memory in the Viking diaspora. Viking and Medieval Scandinavia 4:221-226.

Jesch, J. 2009a. Rögnvaldr jarl Kali Kolsson. Pp. 575609 , In K.E. Gade (Ed.). Poetry from the Kings' Sagas 2. Brepols, Turnhout, Belgium. 914 pp.

Jesch, J. 2009b. The Orcadian links of Snorra Edda. Pp. 145-172, In J.G. Jørgensen (Ed.). Snorres Edda i europeisk og islandsk kultur. Snorrastofa, Reykholt, Iceland. $189 \mathrm{pp}$.

Knirk, J.E. 1994. Learning to write with runes in medieval Norway. Pp. 169-210, In I. Lindell (Ed.). Medeltida skrift- och språkkultur. Stockholms universitet, Stockholm, Sweden. 228 pp.

Meissner, R. 1925. Ermengarde Vicegräfin von Narbonne, und Jarl Rögnvald. Arkiv för nordisk filologi 41:140-191.

Samnordisk runtextdatabas. 2008. Version 2.5. Available online at http://www.runforum.nordiska.uu.se/samnord/. Accessed March 2013.

Spurkland, T. 2005. Norwegian Runes and Runic Inscriptions. Boydell, Woodbridge, UK. 206 pp. 


\section{Endnotes}

${ }^{1}$ Rögnvaldr's biography is derived from Orkneyinga saga, which is cited here by chapter number from the edition by Finnbogi Guðmundsson (1965).

${ }^{2}$ Rögnvaldr's poetry is referred to both by the number of the chapter of Orkneyinga saga in which it is cited (according to the edition by Finnbogi Guðmundsson [1965]) and by the page number(s) of my recent edition in Jesch (2009a). Further references for the various points made in connection with individual stanzas can be found in the latter.

${ }^{3}$ This topic will be explored in detail in a forthcoming monograph. 